\title{
The effect of different dietary sodium levels on the growth performance of broiler chickens, gastrointestinal function, excreta moisture and tibia mineralization*
}

\author{
J. Jankowski ${ }^{1,3}$, Z. Zduńczyk ${ }^{2}$, J. Juśkiewicz ${ }^{2}$ and P. Kwieciński ${ }^{1}$ \\ ${ }^{1}$ University of Warmia and Mazury in Olsztyn, Department of Poultry Science \\ Oczapowskiego 5, 10-718 Olsztyn, Poland \\ ${ }_{2}^{2}$ Institute of Animal Reproduction and Food Research, Polish Academy of Sciences \\ Tuwima 10, 10-747 Olsztyn, Poland
}

Received 25 October 2010; revised version 28 February 2011; accepted 12 March 2011)

\begin{abstract}
The objective of this study was to determine the response of broiler chickens to different dietary sodium (Na) levels. The experiment was performed on 432 male Ross 308 chickens, kept in threetier battery cages, each with a floor area of $0.5 \mathrm{~m}^{2}$. The chickens were divided into six experimental groups of eight replicates, each of nine birds. Six experimental diets were prepared: a basal diet without additional $\mathrm{Na}$ source and diets supplemented with $\mathrm{NaCl}$ in the amount of $0.52,1.03,1.54$, 2.05 and $2.54 \mathrm{~g} / \mathrm{kg}$ in the starter period (1-14 days) and 1.27, 2.54, 3.82, 5.09 and $6.36 \mathrm{~g} / \mathrm{kg}$ in the grower period (15-35 days). The dietary $\mathrm{Na}, \mathrm{Cl}$ and $\mathrm{K}$ content was $0.22-2.61,1.11-4.81$ and $8.76-9.61 \mathrm{~g} / \mathrm{kg}$, respectively. Dietary electrolyte balance (DEB), defined as $\mathrm{Na}^{+}+\mathrm{K}^{+}-\mathrm{Cl}^{-}$, averaged $210 \mathrm{mEq} / \mathrm{kg}$ in all diets.

The $\mathrm{Na}$ content of basal diets was very low $(0.33 \mathrm{~g} / \mathrm{kg}$ in starter diets and $0.22 \mathrm{~g} / \mathrm{kg}$ in grower diets). It inhibited the growth of broilers despite a high DEB resulting from a high $\mathrm{K}$ content (about $9 \mathrm{~g} / \mathrm{kg}$ ). The addition of $\mathrm{NaCl}$ to starter diets significantly increased the body weight (BW) of chickens, but only to the amount of $1.1 \mathrm{~g}$ Na per $\mathrm{kg}$ feed. The addition of $2.54 \mathrm{~g} \mathrm{NaCl}$ per kg grower diets increased the $\mathrm{Na}$ and $\mathrm{Cl}$ content of the diet to $1.16 \mathrm{~g} / \mathrm{kg}$ and $2.68 \mathrm{~g} / \mathrm{kg}$, respectively, leading to a significant improvement in overall production results, slaughter value and tibia mineralization, without negative effect on excreta moisture. A further increase in the $\mathrm{Na}$ content of grower diets (to $1.69,2.18$ and $2.61 \mathrm{~g} / \mathrm{kg}$, respectively), accompanied by an increase in $\mathrm{Cl}$ concentrations (to 3.38, 4.11 and $4.81 \mathrm{~g} / \mathrm{kg}$, respectively) did not increase the BW of chickens, feed conversion efficiency
\end{abstract}

\footnotetext{
* Supported by the National Centre for Research and Development, Project No. R12 009606

${ }^{3}$ Corresponding author: e-mail: janj@uwm.edu.pl
} 
and slaughter value, while it increased excreta moisture and decreased parameters characterizing the mineralization and elasticity of the tibia in birds fed a diet with the highest Na content $(2.61 \mathrm{~g} /$ $\mathrm{kg}$ ). As compared to the group fed the basal diet, the medium and highest $\mathrm{Na}$ dosages significantly decreased $\mathrm{pH}$ and dry matter concentration of small intestine contents; the treatment with the highest dietary $\mathrm{Na}$ levels stimulated bacterial $\beta$-glucosidase and $\beta$-glucuronidase, yet it did not increase the caecal short-chain fatty acids concentration.

KEY WORDS: broiler chicken, Na supplementation, electrolyte balance, performance, excreta moisture, tibia mineralization

\section{INTRODUCTION}

In intensively raised fast-growing chickens an adequate intake of dietary Na has a beneficial influence on feed consumption and the growth rate of birds (Borges et al., 2004), while increased dietary $\mathrm{Na}$ and $\mathrm{Cl}$ levels contribute to litter wetness (Vieira et al., 2003). In many experiments the growth performance of birds was improved when the Na content of feed was increased to 2-3 g/ $\mathrm{kg}$ (Oviedo-Rondon et al., 2001; Mushtaq et al., 2007), i.e. above the NCR (1994) recommendations. An increase in dietary Na to $3 \mathrm{~g} / \mathrm{kg}$ was also found to improve breast muscle yield, and to reduce abdominal fat deposition (Mushtaq et al., 2005).

The negative consequences of an increased dietary intake of $\mathrm{Na}$ include higher water consumption levels and a higher moisture content of litter (Mushtaq et al., 2007) which increases the risk of many diseases (including foot pad dermatitis FPD) and other health problems encountered in poultry production (Juśkiewicz et al., 2009). That is why the Na intake recommendations of the German Society of Nutrition Physiology (GfE, 1999) were established at a relatively low level of $1.3,1.1$ and $0.9 \mathrm{~g} / \mathrm{kg}$ at successive growth stages, much lower than the NRC (1994) and Smulikowska and Rutkowski (2005) recommendations and the values recommended by Oviedo-Rondon et al. (2001) and Mushtaq et al. (2007). Koreleski et al. (2010) showed that at high level of dietary K and moderate level of dietary $\mathrm{Cl}$, the $\mathrm{Na}$ requirement for adequate chicken performance equalled 1.21.7 and $1.25-1.6 \mathrm{~g} / \mathrm{kg}$ in the starter and grower period of feeding, respectively, but the increased dietary level of $\mathrm{Na}$ was associated with enhanced daily nitrogen intake and excretion. The interactions between major ions in the diet are referred to as a dietary electrolyte balance (DEB) defined as $\mathrm{Na}^{+}+\mathrm{K}^{+}-\mathrm{Cl}^{-}$(Mongin, 1981). Depending on housing conditions (mostly indoor temperature), the optimum DEB value in broiler diets should oscillate around $250 \mathrm{mEq} / \mathrm{kg}$ (Mongin, 1981) or vary over a wider range of $220-270 \mathrm{mEq} / \mathrm{kg}$ (Mushtaq et al., 2007). As demonstrated by Borges et al. (2004), DEB of $236 \mathrm{mEq} / \mathrm{kg}$ is recommended for optimum body weight gain in broiler chickens, while a lower value of $207 \mathrm{mEq} / \mathrm{kg}$ supports optimum feed conversion. 
Research results show that the dietary $\mathrm{Na}$ to $\mathrm{Cl}$ ratio of $1: 1$ is required to maintain DEB (Hurwitz et al., 1973). As the above elements have opposite functions in maintaining electrolyte balance, similar DEB values may be achieved at various levels of $\mathrm{NaCl}$ supplementation and a different $\mathrm{Na}$ content of the diet. Since the EU ban on the use of meat-and-bone meals, which were a rich source of $\mathrm{Na}$, dietary $\mathrm{Na}$ supplementation has become a more important consideration. The DEB value recommended in Poland, at $120 \mathrm{mEq} / \mathrm{kg}$ (Smulikowska and Rutkowski, 2005), is substantially lower than the values cited above, whereas the recommended $\mathrm{Na}$ content of poultry diets is considerably above the GfE (1999) recommendations.

The objective of this study was to determine the effect of different dietary $\mathrm{Na}$ levels, at a stable electrolyte balance (above $200 \mathrm{mEq} / \mathrm{kg}$ ) on the growth performance and slaughter value of broiler chickens, their gastrointestinal function, excreta moisture and tibia mineralization.

\section{MATERIAL AND METHODS}

\section{Birds and housing}

The experiment was carried out at the Research Laboratory of the Department of Poultry Science, University of Warmia and Mazury in Olsztyn, on 432 male Ross 308 broiler chickens, from 1 to 35 days of age, kept in three-tier battery cages, each with a floor area of $0.5 \mathrm{~m}^{2}$. The temperature and lighting programme was consistent with the recommendations of the Aviagen Inc. (2007). The birds had free access to feed and water. The chickens were divided into six experimental groups of eight replicates, each of nine birds.

\section{Diets}

All experimental diets had identical composition, corresponding to the nutrient requirements of broiler chickens (Table 1), and they differed only with respect to the level of $\mathrm{NaCl}$ supplementation (Table 2). Looking for the possibilities to reduce $\mathrm{Na}$ content of diets at the first stage of rearing (1-14 days), the maximum $\mathrm{Na}$ contents has been adopted correspondingly to the level recommended by GfE (1999), which resulted in $0.1 \% \mathrm{NaCl}$ addition to diet. Taking into account the response of young birds during the first two weeks of feeding, after starter period the $\mathrm{NaCl}$ content of grower diets (15-35 days) was recalculated and ranged from the value below the GfE (1999) recommendations to over $2.0 \mathrm{~g} / \mathrm{kg}$, believed to stimulate the growth of broilers 
Table 1. Composition and nutritional value of basal starter (1-14 days) and grower (15-35 days) diets, $\%$

\begin{tabular}{lcc}
\hline Specification & Starter diet & Grower diet \\
\hline Ingredient & & \\
wheat & 19.60 & 20.52 \\
maize & 40.00 & 40.00 \\
soyabean meal & 34.15 & 30.60 \\
soyabean oil & 2.24 & 5.12 \\
limestone & 1.57 & 1.56 \\
monocalcium phosphate & 1.31 & 1.12 \\
L-lysine HCL & 0.27 & 0.26 \\
DL-methionine 99 & 0.29 & 0.25 \\
L-threonine & 0.07 & 0.07 \\
vitamin-mineral premix ${ }^{1}$ & 0.50 & 0.50 \\
Calculated & & \\
ME, kcal/kg & 2950 & 3150 \\
crude protein & 21.5 & 20.0 \\
Ca & 0.95 & 0.90 \\
available P & 0.45 & 0.40 \\
Na & 0.02 & 0.02 \\
Cl & 0.08 & 0.07 \\
${ }^{1}$ content per kg feed: IU: vit. A 12 500, vit. $\mathrm{D}_{3} 3500 ; \mathrm{mg}:$ vit. E 50, vit. $\mathrm{K}_{3} 3$ 3, vit. $\mathrm{B}_{1} 3$, vit. $\mathrm{B}_{2} 8$, vit. \\
$\mathrm{B}_{6}$ 5, vit. $\mathrm{B}_{12}$ 0.025, biotin 0.25, Fe 50, Mn 100, Zn 100, Cu 12, J 1, Se 0.3, calcium pantothenate \\
12, nicotinic acid 50, folic acid 2, choline chloride 400
\end{tabular}

Table 2. $\mathrm{NaCl}$ supplementation, $\mathrm{Na}, \mathrm{K}, \mathrm{Cl}$ content $(\mathrm{g} / \mathrm{kg})$ and dietary electrolyte balance (DEB, $\mathrm{mEq} / \mathrm{kg}$ ) in experimental diets

\begin{tabular}{|c|c|c|c|c|c|c|}
\hline \multirow{2}{*}{$\begin{array}{l}\text { Feeding } \\
\text { period }\end{array}$} & \multirow{2}{*}{ Group } & \multirow{2}{*}{$\begin{array}{l}\mathrm{NaCl} \text { addition, } \\
\mathrm{g} / \mathrm{kg}\end{array}$} & \multicolumn{3}{|c|}{ Content in diet, $\mathrm{g} / \mathrm{kg}$} & \multirow{2}{*}{$\begin{array}{c}\mathrm{DEB} \\
\mathrm{mEq} / \mathrm{kg}\end{array}$} \\
\hline & & & $\mathrm{Na}$ & $\mathrm{K}$ & $\mathrm{Cl}$ & \\
\hline \multirow{6}{*}{ 1-14 days } & 1 & 0 & 0.33 & 9.39 & 1.44 & 213 \\
\hline & 2 & 0.52 & 0.57 & 9.61 & 1.71 & 222 \\
\hline & 3 & 1.03 & 0.76 & 9.46 & 2.03 & 218 \\
\hline & 4 & 1.54 & 0.98 & 9.54 & 2.30 & 222 \\
\hline & 5 & 2.05 & 1.10 & 9.41 & 2.68 & 213 \\
\hline & 6 & 2.54 & 1.37 & 9.48 & 3.04 & 216 \\
\hline \multirow{6}{*}{$\begin{array}{l}15-35 \\
\text { days }\end{array}$} & 1 & 0 & 0.22 & 8.91 & 1.11 & 206 \\
\hline & 2 & 1.27 & 0.74 & 9.00 & 1.98 & 207 \\
\hline & 3 & 2.54 & 1.16 & 8.86 & 2.68 & 202 \\
\hline & 4 & 3.82 & 1.69 & 8.79 & 3.38 & 203 \\
\hline & 5 & 5.09 & 2.18 & 8.90 & 4.11 & 207 \\
\hline & 6 & 6.36 & 2.61 & 8.76 & 4.81 & 202 \\
\hline
\end{tabular}

(Oviedo-Rondon et al., 2001; Watkins et al., 2005; Mushtaq et al., 2007). At the age of 15 days all birds from groups 2-6 were pooled and again divided into five groups that comprised birds with similar initial (at the beginning of the second feeding stage) body weight (Table 3 ). 
Table 3. Body weight (BW), body weight gain (BWG) and feed conversion ratio (FCR) at different stages of the study of the broilers (mean for 8 replications)

\begin{tabular}{|c|c|c|c|c|c|c|c|c|}
\hline & \multicolumn{6}{|c|}{ Experimental group } & \multirow{2}{*}{ SEM } & \multirow{2}{*}{$\mathrm{P}$} \\
\hline & 1 & 2 & 3 & 4 & 5 & 6 & & \\
\hline \multicolumn{9}{|l|}{$B W, g$} \\
\hline day 1 & 42 & 43 & 42 & 42 & 42 & 42 & 15 & 0.535 \\
\hline day 14 & $240^{\mathrm{E}}$ & $324^{\mathrm{D}}$ & $387^{\mathrm{C}}$ & $421^{B}$ & $446^{\mathrm{A}}$ & $461^{\mathrm{A}}$ & 12 & $<0.001$ \\
\hline day $15^{1}$ & $240^{\mathrm{B}}$ & $404^{\mathrm{A}}$ & $412^{\mathrm{A}}$ & $407^{\mathrm{A}}$ & $398^{\mathrm{A}}$ & $403^{\mathrm{A}}$ & 15 & $<0.001$ \\
\hline day 35 & $716^{\mathrm{C}}$ & $1890^{\mathrm{B}}$ & $2053^{\mathrm{A}}$ & $2052^{\mathrm{A}}$ & $2090^{\mathrm{A}}$ & $2109^{\mathrm{A}}$ & 74 & $<0.001$ \\
\hline \multicolumn{9}{|l|}{$B W G, g$} \\
\hline 1-14 days & $198^{\mathrm{E}}$ & $281^{\mathrm{D}}$ & $345^{\mathrm{C}}$ & $379^{\mathrm{B}}$ & $403^{\mathrm{AB}}$ & $419^{\mathrm{A}}$ & 12 & $<0.001$ \\
\hline 15-35 days & $476^{\mathrm{C}}$ & $1486^{\mathrm{B}}$ & $1641^{\mathrm{A}}$ & $1645^{\mathrm{A}}$ & $1692^{\mathrm{A}}$ & $1706^{\mathrm{A}}$ & 64 & $<0.001$ \\
\hline \multicolumn{9}{|l|}{$F C R$} \\
\hline 1-14 days & $1.55^{\mathrm{A}}$ & $1.37^{\mathrm{B}}$ & $1.31^{\mathrm{B}}$ & $1.17^{\mathrm{C}}$ & $1.20^{\mathrm{C}}$ & $1.20^{\mathrm{C}}$ & 0.025 & $<0.001$ \\
\hline 15-35 days & $2.73^{\mathrm{A}}$ & $1.86^{\mathrm{B}}$ & $1.73^{\mathrm{B}}$ & $1.72^{\mathrm{B}}$ & $1.72^{\mathrm{B}}$ & $1.74^{\mathrm{B}}$ & 0.061 & $<0.001$ \\
\hline
\end{tabular}

The dietary $\mathrm{Na}$ levels were reached by adding a premix containing $\mathrm{NaCl}$. The premix, different for each diet and prepared under laboratory conditions, was thoroughly mixed with the basal mash diet $(1: 99 \mathrm{w} / \mathrm{w})$. Samples of experimental diets were assayed for the content of $\mathrm{Na}, \mathrm{K}$ - by atomic absorption using a spectrophotometer Avanta (GBC Braeside, Australia) and $\mathrm{Cl}$ - by the biamperometric technique using an apparatus PAM-11 (Gdańsk, Poland). DEB was calculated using the formula developed by Mongin (1981).

\section{Sample collection and chemical analyses}

Excreta samples were collected on day 14 and 35 to determine the moisture content. On day 35 , all chickens were weighed and seven birds with a body weight near to average of each group were slaughtered. After evisceration, liver, gizzard, heart, kidneys, spleen and adrenal glands were dissected and weighed. After $24 \mathrm{~h}$ of chilling at $4^{\circ} \mathrm{C}$ carcass was weighed, breast, thigh and drumstick muscles, abdominal fat and tibia bones were dissected and weighed.

Samples of ileal and caecal digesta were collected from eight chickens with a body weight near to average from three groups fed diets with the lowest, medium and highest $\mathrm{Na}$ content. After laparotomy, segments of the digestive tract (small intestine and caeca) were removed and weighed. As soon as possible after euthanasia (about $20 \mathrm{~min}$ ), $\mathrm{pH}$ of ileal and caecal digesta were measured using a microelectrode and a $\mathrm{pH} / \mathrm{ION}$ meter (model 301, Hanna Instruments, Vila do Conde, Portugal). Small intestinal and caecal contents were sampled for an analysis of dry matter and short-chain fatty acids (SCFA) concentrations, while the remaining part of the caecal digesta was transferred to test tubes and 
stored at $-70^{\circ} \mathrm{C}$ until needed. The caeca were flushed with water, blotted on filter paper and weighed. The small intestine was divided into four equal sections, the second part (representing jejunum) from the gizzard side was rinsed with icecold physiological saline and cut open. The mucosal samples were collected by scraping with glass slides on an iced glass plate, weighed and subsequently stored at $-70^{\circ} \mathrm{C}$.

The levels of mucosal sucrase and maltase activity were assayed by the method of Dahlqvist (1964). The amount of liberated glucose was measured spectrophotometrically and the enzyme activity was expressed as $\mu \mathrm{mol}$ disaccharide hydrolysed per min and $\mathrm{g}$ of protein. The activity of bacterial $\beta$-glucosidase and $\beta$-glucuronidase in the caecal digesta was measured by the rate of p-nitrophenol release from nitrophenylglucosides according to the modified method of Djouzi and Andrieux (1997), as described by Juśkiewicz and Zduńczyk (2004). The following substrates were used: p-nitrophenyl-bD-glucopyranoside for b-glucosidase and p-nitrophenyl-b-D-glucuronide for b-glucuronidase. The reaction mixture contained $0.3 \mathrm{ml}$ of substrate solution $(5 \mathrm{mM})$ and $0.2 \mathrm{ml}$ of a $1: 10(\mathrm{v} / \mathrm{v})$ dilution of the caecal sample in $100 \mathrm{mM}$ phosphate buffer $\left(\mathrm{pH} \mathrm{7.0)}\right.$. Incubation was carried out at $39^{\circ} \mathrm{C}$. Following the addition of $2.5 \mathrm{ml}$ of $0.25 \mathrm{M}$ cold $\mathrm{Na}$ carbonate and centrifugation at $7.211 \mathrm{~g}$ for $15 \mathrm{~min}$ at a temperature of $21^{\circ} \mathrm{C}$, absorbance was measured at $400 \mathrm{~nm}$. Enzyme activity (IU) was expressed as $\mu \mathrm{mol}$ of p-nitrophenol formed per min and per $\mathrm{g}$ of digesta. Caecal digesta samples were subjected to SCFA analysis using gasliquid chromatography (Shimadzu GC-14A Shimadzu Co., Kyoto, Japan). The samples $(0.2 \mathrm{~g})$ were mixed with $0.2 \mathrm{ml}$ formic acid, diluted with deionized water and centrifuged at $7.211 \mathrm{~g}$ for $5 \mathrm{~min}$. The supernatant was loaded onto a glass chromatography column $(2.5 \mathrm{~m}$ x $2.6 \mathrm{~mm})$ packed with $10 \% \mathrm{SP}-1200 / 1 \% \mathrm{H}_{3} \mathrm{PO}_{4}$ on 80/100 Chromosorb W AW (Supelco Co., Bellefonte, PA). The chromatograph was coupled to a flame ionization detector. Column injector and detector temperatures were 110,195 and $180^{\circ} \mathrm{C}$, respectively.

Mineralization parameters were determined on tibia bones collected from birds subjected to a carcass analysis. The left tibias were used for chemical analyses, and the right tibias were used for strength tests. Tibia breaking strength (3-point bending test) was measured with the use of an Instron 4301 (USA) tensile testing machine with head duty of up to $1 \mathrm{kN}$ and crosshead speed of $5 \mathrm{~mm} / \mathrm{min}$. Dynamic load was applied perpendicularly to the axis of the long bone. The procedure of fracturing bones and the process of saving data files were fully automated (Ferretti et al., 1993). Load force was recorded during the test at $1 / 20 \mathrm{~s}$ intervals. The minimum breaking strength of tibia bones was also determined. To estimate the dry matter and degree of tibia mineralization, $1 \mathrm{~g}$ samples were collected from the middle part of the bones. The samples were mineralized in a mixture $(3: 1)$ 
of nitric acid and perchloric acid (Merck, Germany). To determine the content of ash, $\mathrm{Ca}$ and $\mathrm{P}$ in the tibia, weighted samples were mineralized in a VELP DK 20 electric aluminum heating block with selectable temperatures (VELP Scientifica, Italy). Analytical samples were prepared together with test samples. The $\mathrm{Ca}$ content of mineralizates was determined by flame atomic absorption spectrometry (acetylene-air flame). The analysis was performed with the use of a Unicam 939 Solar atomic absorption spectrophotometer equipped with an Optimus data station, background correction system (deuterium lamp) and cathode lamps. The P content of mineralizates was determined by colorimetry, using ammonium molybdate, $\mathrm{Na}$ sulphate and hydroquinone. Absorbance was measured with the use of a VIS 6000 spectrophotometer (Krüss-Optronic, Germany) at a wavelength of $\lambda=610 \mathrm{~mm}$.

\section{Calculations and statistical analysis}

The relative weight (g per $100 \mathrm{~g}$ of live body weight) of liver, gizzard, heart, kidneys, spleen and adrenal glands were calculated. Dressing percentage and relative weight (g per $100 \mathrm{~g}$ of carcass) of breast, thigh and drumstick muscles, abdominal fat and tibial bones were calculated. Results were analysed by oneway analysis of variance (ANOVA) in orthogonal and non-orthogonal designs. The significance of differences was estimated by Duncan's test. Differences were considered to be significant at $\mathrm{P}<0.01$ and $\mathrm{P}<0.05$. The calculations were performed using the STATISTICA software package ver. 9.0.

\section{RESULTS}

Basal starter and grower diets had a very low Na content, 0.33 and $0.22 \mathrm{~g} / \mathrm{kg}$, respectively (Table 2). The $\mathrm{Na}$ content of diets supplemented with $\mathrm{NaCl}$ ranged from 0.57 to $1.37 \mathrm{~g} / \mathrm{kg}$ at the first stage of feeding, and from 0.74 to $2.61 \mathrm{~g} / \mathrm{kg}$ at the second stage. The $\mathrm{Cl}$ content of experimental diets varied over a wider range, from below $2.0 \mathrm{~g} / \mathrm{kg}$ to nearly $5.0 \mathrm{~g} / \mathrm{kg}$. The $\mathrm{K}$ content of starter and grower diets amounted to 9.5 and $8.9 \mathrm{~g} / \mathrm{kg}$, respectively. The average DEB values oscillated around $210 \mathrm{mqE} / \mathrm{kg}$ over the entire experimental period, regardless of $\mathrm{NaCl}$ inclusion levels.

The differences in the electrolyte composition of experimental diets affected the body weight gains of chickens in both analysed periods (Table 3). In the starter period (1-14 days), the groups differed significantly $(\mathrm{P}<0.01)$ with respect to the body weight of birds, as follows: $1<2<3<4<5,6$ (Table 3). In the grower period (15-35 days), significant differences in weight gains were noted between groups 1 and 2, and 3-6. At both stages of feeding, significantly higher feed intake 
per kg body weight gain was observed in group 1 birds fed a diet without $\mathrm{NaCl}$ ( $\mathrm{P}<0.001$ vs all groups). In the starter period, FCR values were significantly lower in groups 4-6 than in groups 2 and 3, while in the grower period there were not significant differences in FCR values between groups fed $\mathrm{NaCl}$-supplemented diets. During the entire experiment, no death cases were reported in the group fed a diet with the lowest $\mathrm{Na}$ content, and in the remaining groups mortality rates were low, in the $1.39-2.78 \%$ range.

Broilers fed diets with a considerably different $\mathrm{Na}$ content (groups 1, 4 and 6) differed with regard to some parameters of gastrointestinal function (Table 4).

Table 4. Parameters of gastrointestinal function at the age of 35 days

\begin{tabular}{|c|c|c|c|c|c|}
\hline \multirow{2}{*}{ Item } & \multicolumn{3}{|c|}{ Group $^{1}$} & \multirow{2}{*}{ SEM } & \multirow{2}{*}{$\mathrm{P}$} \\
\hline & 1 & 4 & 6 & & \\
\hline \multicolumn{6}{|l|}{ Small intestine parameters: } \\
\hline full weight, $\mathrm{g} / \mathrm{kg} \mathrm{BW}$ & $47.0^{\mathrm{a}}$ & $43.7^{\mathrm{ab}}$ & $42.5^{\mathrm{b}}$ & 0.910 & 0.004 \\
\hline $\mathrm{pH}$ of digesta & $5.77^{\mathrm{a}}$ & $5.22^{\mathrm{b}}$ & $5.27^{\mathrm{b}}$ & 0.109 & 0.045 \\
\hline dry matter of digesta, $\%$ & $19.3^{\mathrm{a}}$ & $17.2^{\mathrm{b}}$ & $17.4^{\mathrm{b}}$ & 0.294 & 0.002 \\
\hline viscosity of digesta, $\mathrm{mPas}$ & $2.11^{\mathrm{a}}$ & $1.65^{\mathrm{b}}$ & $2.20^{\mathrm{a}}$ & 0.090 & 0.021 \\
\hline sucrase activity, $\mu \mathrm{mol} / \mathrm{min} / \mathrm{g}$ & $19.4^{\mathrm{b}}$ & $24.4^{\mathrm{a}}$ & $20.5^{\mathrm{b}}$ & 0.735 & 0.008 \\
\hline maltase activity, $\mu \mathrm{mol} / \mathrm{min} / \mathrm{g}$ & 70.4 & 77.0 & 66.2 & 2.640 & 0.253 \\
\hline aminopeptidase, $\mu \mathrm{mol} / \mathrm{min} / \mathrm{g}$ & 55.9 & 55.3 & 54.1 & 1.691 & 0.911 \\
\hline \multicolumn{6}{|l|}{ Caeca parameters } \\
\hline tissue, $\mathrm{g} / \mathrm{kg} \mathrm{BW}$ & $4.02^{\mathrm{a}}$ & $3.14^{\mathrm{b}}$ & $3.12^{\mathrm{b}}$ & 0.126 & $<0.001$ \\
\hline digesta, $\mathrm{g} / \mathrm{kg} \mathrm{BW}$ & $4.94^{\mathrm{b}}$ & $4.71^{\mathrm{b}}$ & $6.29^{\mathrm{a}}$ & 0.305 & 0.049 \\
\hline $\mathrm{pH}$ of digesta & 6.16 & 6.22 & 6.08 & 0.048 & 0.510 \\
\hline dry matter of digesta, $\%$ & 18.1 & 16.7 & 18.00 & 0.421 & 0.341 \\
\hline$\beta$ - glucosidase, $\mu \mathrm{mol} / \mathrm{h} / \mathrm{g}$ & $4.66^{\mathrm{B}}$ & $4.79^{\mathrm{B}}$ & $8.73^{\mathrm{A}}$ & 0.547 & $<0.001$ \\
\hline$\beta$-glucuronidase, $\mu \mathrm{mol} / \mathrm{h} / \mathrm{g}$ & $16.6^{\mathrm{B}}$ & $16.5^{\mathrm{B}}$ & $34.1^{\mathrm{A}}$ & 2.510 & $<0.001$ \\
\hline total SCFA, $\mu \mathrm{mol} / \mathrm{g}$ & 118.6 & 122.9 & 110.9 & 2.933 & 0.251 \\
\hline acetate, $\mu \mathrm{mol} / \mathrm{g}$ & 83.3 & 81.8 & 75.1 & 2.640 & 0.382 \\
\hline propionate, $\mu \mathrm{mol} / \mathrm{g}$ & $6.15^{b}$ & $8.97^{\mathrm{a}}$ & $7.37^{\mathrm{b}}$ & 0.385 & 0.006 \\
\hline isobutyrate, $\mu \mathrm{mol} / \mathrm{g}$ & $0.68^{\mathrm{b}}$ & $1.21^{\mathrm{a}}$ & $1.12^{\mathrm{a}}$ & 0.077 & 0.005 \\
\hline butyrate, $\mu \mathrm{mol} / \mathrm{g}$ & $26.3^{\mathrm{ab}}$ & $27.5^{\mathrm{a}}$ & $24.3^{\mathrm{b}}$ & 0.752 & 0.049 \\
\hline isovalerate, $\mu \mathrm{mol} / \mathrm{g}$ & $0.86^{\mathrm{b}}$ & $1.51^{\mathrm{a}}$ & $1.35^{\mathrm{a}}$ & 0.126 & 0.047 \\
\hline valerate, $\mu \mathrm{mol} / \mathrm{g}$ & $1.29^{\mathrm{b}}$ & $1.87^{\mathrm{a}}$ & $1.73^{\mathrm{a}}$ & 0.084 & 0.007 \\
\hline
\end{tabular}

values $(\mathrm{n}=8)$ not sharing the same superscript letters within a columns are different at $\mathrm{P}<0.05$ $(\mathrm{a}, \mathrm{b})$ or at $\mathrm{P}<0.01(\mathrm{~A}, \mathrm{~B}) ;{ }^{1} \mathrm{Na}$ content of the grower diet was $0.22,1.69$ and $2.61 \mathrm{~g} / \mathrm{kg}$, respectively

Birds fed a diet with the lowest $\mathrm{Na}$ content, compared with those receiving diets with medium and the highest $\mathrm{Na}$ concentrations, were characterized by higher weight of the small intestine ( $\mathrm{P}<0.05$ vs the group with the highest $\mathrm{Na}$ concentration), a higher $\mathrm{pH}$ and a higher dry matter content of digesta $(\mathrm{P}<0.05 \mathrm{vs}$ the medium and high Na treatments). Mucosal sucrase activity was highest in the group fed a diet with a medium Na content, whereas maltase and aminopeptidase activities were similar in all groups. Chickens fed a diet with the lowest $\mathrm{Na}$ 
content had significantly higher weight of caecal walls, while birds fed a diet with the highest $\mathrm{Na}$ content had the highest weight of caecal digesta. The dry matter content and $\mathrm{pH}$ of caecal digesta were comparable in all groups. Significantly $(\mathrm{P}<0.01)$ higher activities of $\beta$-glucosidase and $\beta$-glucuronidase in the caecal digesta were observed in chickens fed a diet with the highest $\mathrm{Na}$ content. There were no significant differences between groups in the concentrations of total SCFA and the predominant acetic acid. Birds receiving a diet with a medium $\mathrm{Na}$ content were marked by higher concentrations of propionic acid. Significantly higher levels of fatty acids with longer chains (isobutyric, isovaleric and valeric acids) were found in the caecal digesta of chickens fed Na-supplemented diets.

On day 14 , the dry matter content of excreta was similar in all groups (19.2$20.1 \%)$. On day 35 , higher levels of dietary $\mathrm{Na}$ resulted in a falling trend $(\mathrm{P}=0.088)$ in the dry matter content of droppings, which decreased from 24.1 to $24.4 \%$ in groups fed diets without $\mathrm{NaCl}$ and with its lowest content, to $20.5 \%$ in the group receiving a diet with the highest $\mathrm{Cl}$ inclusion level $(6.36 \mathrm{~g} / \mathrm{kg})$ and a $\mathrm{Na}$ content of $2.61 \mathrm{~g} / \mathrm{kg}$ (Table 5).

Table 5. Dry matter content of excreta, \%

\begin{tabular}{|c|c|c|c|c|c|c|c|c|}
\hline \multirow{2}{*}{ Age, days } & \multicolumn{6}{|c|}{ Experimental groups } & \multirow{2}{*}{ SEM } & \multirow[b]{2}{*}{$\mathrm{P}$} \\
\hline & 1 & 2 & 3 & 4 & 5 & 6 & & \\
\hline 14 & 20.0 & 19.8 & 20.1 & 19.1 & 19.2 & 19.4 & 0.242 & 0.432 \\
\hline 35 & 24.1 & 24.4 & 22.4 & 23.0 & 22.1 & 20.5 & 0.364 & 0.088 \\
\hline
\end{tabular}

The carcass dressing percentage of broilers fed Na-supplemented diets was similar (69.8-70.7\%, $\mathrm{P}>0.05)$, while a significantly lower dressing percentage was noted in the group fed a diet without additional $\mathrm{Na}$ (Table 6). The latter group was characterized by significantly higher total relative weight of edible giblets, including the gizzard, and lower relative weight of muscles, including

Table 6. Results of carcass analysis, $\mathrm{g} / 100 \mathrm{~g}$ live body weight

\begin{tabular}{|c|c|c|c|c|c|c|c|c|}
\hline \multirow[b]{2}{*}{ Group } & \multirow{2}{*}{$\begin{array}{l}\text { Dressing } \\
\text { percentage }\end{array}$} & \multicolumn{2}{|c|}{ Muscle weight } & \multicolumn{2}{|c|}{ Edible giblets } & \multirow{2}{*}{$\begin{array}{l}\text { Kidney } \\
\text { weight }\end{array}$} & \multirow{2}{*}{$\begin{array}{c}\text { Adrenal } \\
\text { gland } \\
\text { weight }\end{array}$} & \multirow{2}{*}{$\begin{array}{c}\text { Abdomina } \\
\text { fat }\end{array}$} \\
\hline & & total $^{1}$ & $\begin{array}{l}\text { breast } \\
\text { muscles }\end{array}$ & total $^{2}$ & gizzard & & & \\
\hline$\overline{1}$ & $67.3^{\mathrm{B}}$ & $29.2^{\mathrm{B}}$ & $14.6^{\mathrm{B}}$ & $4.14^{\mathrm{a}}$ & $1.65^{\mathrm{A}}$ & $0.84^{\mathrm{A}}$ & $0.022^{\mathrm{A}}$ & 0.69 \\
\hline 2 & $70.7^{\mathrm{A}}$ & $33.2^{\mathrm{A}}$ & $17.5^{\mathrm{A}}$ & $3.78^{\mathrm{b}}$ & $1.28^{\mathrm{B}}$ & $0.59^{\mathrm{B}}$ & $0.009^{\mathrm{B}}$ & 0.75 \\
\hline 3 & $70.6^{\mathrm{A}}$ & $33.5^{\mathrm{A}}$ & $17.6^{\mathrm{A}}$ & $3.85^{\mathrm{b}}$ & $1.26^{\mathrm{B}}$ & $0.59^{\mathrm{B}}$ & $0.011^{\mathrm{B}}$ & 1.10 \\
\hline 4 & $69.8^{\mathrm{A}}$ & $33.3^{\mathrm{A}}$ & $17.6^{\mathrm{A}}$ & $3.60^{\mathrm{b}}$ & $1.11^{\mathrm{B}}$ & $0.55^{\mathrm{B}}$ & $0.010^{\mathrm{B}}$ & 0.92 \\
\hline 5 & $70.0^{\mathrm{A}}$ & $33.1^{\mathrm{A}}$ & $17.7^{\mathrm{A}}$ & $3.69^{\mathrm{b}}$ & $1.11^{\mathrm{B}}$ & $0.61^{\mathrm{B}}$ & $0.009^{\mathrm{B}}$ & 0.97 \\
\hline 6 & $70.6^{\mathrm{A}}$ & $33.7^{\mathrm{A}}$ & $18.2^{\mathrm{A}}$ & $3.87^{\mathrm{b}}$ & $1.19^{\mathrm{B}}$ & $0.60^{\mathrm{B}}$ & $0.010^{\mathrm{B}}$ & 0.79 \\
\hline SEM & 0.296 & 0.292 & 0.246 & 0.046 & 0.036 & 0.003 & 0.001 & 0.046 \\
\hline $\mathrm{P}$ & 0.003 & $<0.001$ & $<0.001$ & 0.015 & $<0.001$ & $<0.001$ & $<0.001$ & 0.086 \\
\hline
\end{tabular}

values $(\mathrm{n}=7)$ not sharing the same superscript letters within a column are different at $\mathrm{P}<0.01$

$(\mathrm{A}, \mathrm{B})$ and at $\mathrm{P}<0.05(\mathrm{a}, \mathrm{b})$; ${ }^{1}$ breast, thigh and drumstick muscles; ${ }^{2}$ liver, gizzard and heart 
breast muscles. No significant differences were found between groups with respect to carcass fat content. The diet without an additional $\mathrm{Na}$ source contributed to a significant increase in the relative weights of kidneys and adrenal glands, in comparison with the remaining groups where the relative weights of the above organs were comparable.

Although the relative weight of the tibia was comparable in all groups, $\mathrm{Na}$ supplementation affected the majority of the analysed parameters of tibia structure and strength (Table 7). The lowest crude ash content of tibia dry matter was observed both in chickens fed a diet without $\mathrm{NaCl}$ and with the highest addition of $\mathrm{NaCl}(\mathrm{P}<0.05$ vs groups with dietary $\mathrm{Na}$ levels of 0.7 and $1.2 \mathrm{~g} / \mathrm{kg})$.

Table 7. Tibial bone strength and mineralization parameters

\begin{tabular}{lccccc}
\hline Group & $\begin{array}{c}\text { Tibia relative } \\
\text { weight }^{1}\end{array}$ & \multicolumn{3}{c}{ Content, \% DM } & Minimum breaking \\
\cline { 3 - 5 } & 0.49 & $50.71^{\mathrm{b}}$ & $18.03^{\mathrm{b}}$ & $8.69^{\mathrm{B}}$ & $0.229^{\mathrm{C}}$ \\
\hline 1 & 0.54 & $53.82^{\mathrm{a}}$ & $18.83^{\mathrm{ab}}$ & $9.36^{\mathrm{A}}$ & $0.631^{\mathrm{A}}$ \\
2 & 0.53 & $54.81^{\mathrm{a}}$ & $19.51^{\mathrm{a}}$ & $9.41^{\mathrm{A}}$ & $0.615^{\mathrm{AB}}$ \\
3 & 0.51 & $52.09^{\mathrm{ab}}$ & $18.16^{\mathrm{b}}$ & $8.82^{\mathrm{B}}$ & $0.562^{\mathrm{AB}}$ \\
4 & 0.52 & $52.48^{\mathrm{ab}}$ & $18.54^{\mathrm{ab}}$ & $9.06^{\mathrm{AB}}$ & $0.589^{\mathrm{AB}}$ \\
5 & 0.50 & $50.70^{\mathrm{b}}$ & $17.91^{\mathrm{b}}$ & $8.78^{\mathrm{B}}$ & $0.539^{\mathrm{B}}$ \\
6 & 0.006 & 0.403 & 0.154 & 0.072 & 0.025 \\
SEM & 0.120 & 0.020 & 0.017 & 0.003 & $<0.001$ \\
P & & & & &
\end{tabular}

values $(\mathrm{n}=7)$ not sharing the same superscript letters within a column are different at $\mathrm{P}<0.01$ (A, B, C) and at $\mathrm{P}<0.05(\mathrm{a}, \mathrm{b}) ;{ }^{1} \mathrm{~g} / 100 \mathrm{~g}$ live body weight

The concentrations of $\mathrm{Ca}$ and $\mathrm{P}$ in the tibia varied, but they were not correlated with the $\mathrm{Na}$ content of experimental diets. The highest $\mathrm{Ca}$ and $\mathrm{P}$ content of the tibia was reported in broilers fed a diet containing $1.21 \mathrm{~g} \mathrm{Na}$ per $\mathrm{kg}$ feed. The tibias of chickens fed a diet without $\mathrm{NaCl}$ were significantly more prone to breaking. The minimum breaking strength of tibia bones was over two-fold lower in this group $(\mathrm{P}<0.001)$ than in the other groups. Among birds receiving $\mathrm{NaCl}$-supplemented diets, the highest and lowest breaking strength was noted in groups fed diets with $\mathrm{Na}$ content of 0.78 and $2.66 \mathrm{~g} / \mathrm{kg}$, respectively $(\mathrm{P}<0.05)$.

\section{DISCUSSION}

Based on the nutrient requirements of chickens (NRC, 1994), the Na content should be 2 and $1.5 \mathrm{~g} / \mathrm{kg}, \mathrm{Cl}$ content 2 and $1.5 \mathrm{~g} / \mathrm{kg}, \mathrm{K}$ content $3.0 \mathrm{~g} / \mathrm{kg}$ in starter and grower diets, respectively. According to broiler producers (Aviagen Inc., 2007), the levels of this electrolytes in chicken diets should be higher, $\mathrm{Na}$ and $\mathrm{Cl} 2.3$ $1.6 \mathrm{~g} / \mathrm{kg}$, and $9.0-4.0 \mathrm{~g} / \mathrm{kg}$ for K. According to the GfE (1999) recommendations, 
the above values should range from 1.3 to $0.9 \mathrm{~g} / \mathrm{kg}$ for $\mathrm{Na}$ and $\mathrm{Cl}$, and from 2.9 to $2.0 \mathrm{~g} / \mathrm{kg}$ for $\mathrm{K}$. In our study, cereals and soyabean meal, the major components of experimental diets, supplied various amounts of electrolytes, deficient in the case of $\mathrm{Na}(0.33$ and $0.22 \mathrm{~g} / \mathrm{kg}$ in the starter and grower diets, respectively), relatively high in that of $\mathrm{Cl}(1.44$ and $1.11 \mathrm{~g} / \mathrm{kg})$ and very high in that of $\mathrm{K}(9.39$ and $8.91 \mathrm{~g} / \mathrm{kg}$ ). The applied various levels of $\mathrm{NaCl}$ increased the dietary $\mathrm{Na}$ content, from 0.57 to $1.37 \mathrm{~g} / \mathrm{kg}$ at the first stage of fattening, and from 0.74 to $2.61 \mathrm{~g} / \mathrm{kg}$ at the second stage, i.e. from below to above the recommended values (NRC, 1994; Aviagen Inc., 2007). As a result, $\mathrm{Cl}$ content of diets was also increased, even above the aforementioned recommended levels.

The results of numerous studies indicate that an increase in Na content of the ration is followed by an improvement in the growth performance of broilers and feed conversion efficiency (Mongin, 1981; Vieira et al., 2003). However, the risk of death increases when $\mathrm{Na}$ inclusion levels exceed $3.5 \mathrm{~g} / \mathrm{kg}$ (Vieira et al., 2003). In the present experiment, no death cases were reported in the groups fed diets with the lowest and highest $\mathrm{Na}$ content. The growth inhibition of group 1 chickens suggests that a relatively high DEB, above $200 \mathrm{mEq} / \mathrm{kg}$, does not meet the nutrient requirements of birds if $\mathrm{Na}$ is supplied solely by feed components. The addition of $\mathrm{NaCl}$ to such diets significantly improved production results. At the first stage of feeding (1-14 days), an increase in the Na content of the ration to $1.1 \mathrm{~g} / \mathrm{kg}$ was clearly found to be effective, but a further increase of dietary $\mathrm{Na}$ level to $1.37 \mathrm{~g} / \mathrm{kg}$ did not support the BWG of broilers. At the second stage of feeding (15-35 days), a significant increase in the final body weights of chickens was achieved by increasing the $\mathrm{Na}$ content of experimental diets from 0.22 to 0.74 and $1.16 \mathrm{~g} / \mathrm{kg}$. Higher dietary $\mathrm{NaCl}$ levels, which increased the Na content of diets to $1.69-2.61 \mathrm{~g} / \mathrm{kg}$, did not increase the final body weights of chickens and did not improve the feed conversion ratio.

One of the few experiments investigating the effects of $\mathrm{Na}$ on gastrointestinal function showed that an increase in dietary $\mathrm{Na}$ intake from 0.5 to $3.2 \mathrm{~g} / \mathrm{kg}$ enhanced the activity of intestinal ATPases involved in nutrient transport in the small intestine (Gal-Garber et al., 2003). The cited authors observed also an increase in intestinal weight, which could result from increased water intake. A positive correlation between water intake and the $\mathrm{Na}$ content of diets in broiler chickens has been reported by numerous authors (e.g., Mushtaq et al., 2007). Also in our study Na-supplemented diets increased the hydration of the small intestinal contents of birds. Additional $\mathrm{Na}$ decreased the $\mathrm{pH}$ of small intestinal digesta, it had ambiguous effects of the activities of jejunal mucosal enzymes, but it affected selected parameters of caecal function. In comparison with the Nadeficient group, the addition of $\mathrm{Na}$ increased the weight of caecal digesta and stimulated the glycolytic activity of intestinal microbiota, yet it did not increase 
the concentrations of SCFA. A higher $\mathrm{NaCl}$ content of intestinal digesta could support intensive fermentation of carbohydrates (as suggested by higher activity of glycolytic microflora) as well as the absorption of volatile fatty acids from the intestinal contents. According to Gal-Garber et al. (2003), Na plays an active role in nutrient transport across the intestinal wall.

A trend $(\mathrm{P}=0.088)$ towards an increase in excreta moisture was observed in our study. Due to a lower Na content of experimental diets, the chickens' response was less pronounced than in other experiments where increasing concentrations of $\mathrm{Na}$ ions in the ration enhanced water intake and decreased the dry matter content of droppings (Vieira et al., 2003; Enting et al., 2009). The above suggests that dietary $\mathrm{Na}$ intake should be reduced to effectively control litter wetness and the incidence of foot pat dermatitis (Oviedo-Rondon et al., 2001).

The carcass analysis revealed symptoms of malnutrition only in chickens fed a diet without additional $\mathrm{Na}$, including a lower dressing percentage, a higher percentage content of edible giblets and a lower muscle content of the carcass. Chickens fed a diet with the lowest $\mathrm{Na}$ content had lower final body weights, but their carcass parameters were similar to those noted in birds receiving higher amounts of $\mathrm{NaCl}$. Other authors also reported that dietary $\mathrm{Na}$ intake had no influence on the slaughter quality of broilers (Bidar et al., 2007) or that its effect was limited to lowering abdominal fat deposition (Mushtaq et al., 2007).

In the present experiment, chickens fed a diet without $\mathrm{NaCl}$ had significantly higher relative weights of kidneys and adrenal glands, most probably due to lower feed consumption and lower weight gains. Malnourishment manifests itself in a decrease in total muscle weight accompanied by an increase in the relative weights of internal organs (Yu and Robinson, 1992). In the remaining groups, the relative weights of kidneys and adrenal glands were not affected by an increase in $\mathrm{NaCl}$ inclusion levels from 0.127 to $0.636 \%(0.74-2.61 \mathrm{~g} / \mathrm{kg}$ supplemental $\mathrm{Na})$.

According to a few researchers, $\mathrm{Na}$ and other electrolytes contribute to the growth and mineralization of bone tissue. In a study by Murakami et al. (1997), the ash content of bones decreased along with an increase in the Na content of chicken diets. Another experiment by the cited authors (Murakami et al., 2000) showed that dietary $\mathrm{Na}$ intake of $1.5 \mathrm{~g} / \mathrm{kg}$ is required for adequate tibia mineralization in broilers. In our study, a Na-deficient diet caused a significant decrease in the crude ash and $\mathrm{P}$ content of tibia dry matter, which made the bones susceptible to breaking more easily. The minimum breaking strength of tibial bones was over two-fold lower in this groups than in the remaining groups. The highest concentrations of $\mathrm{Na}$ and $\mathrm{Cl}$ in grower diets ( 2.61 and $4.81 \mathrm{~g} / \mathrm{kg}$, respectively) had also an adverse impact on the studied parameters of tibia mineralization. Apart from the aforementioned group, chickens fed diets with different $\mathrm{NaCl}$ addition $(1.27-5.09 \mathrm{~g} / \mathrm{kg})$ did not differ significantly with respect to bone breaking strength. 
The results of the present study show that at the first stage of feeding (1-14 days), $1.10 \mathrm{~g} \mathrm{Na}$ per $\mathrm{kg}$ feed was required for good production results, while starting from day 15 the amount of $\mathrm{Na}$ sufficient to ensure the desired growth rate of chickens was $1.16 \mathrm{~g} / \mathrm{kg}$. In the grower period, an increase in Na supplementation accompanied by an increase in the $\mathrm{Cl}$ content of diets did not contribute to a significant increase in the final body weight of chickens and carcass lean content, while it increased excreta moisture and decreased parameters characterizing the mineralization of the tibia in birds fed a diet with the highest $\mathrm{Na}$ and $\mathrm{Cl}$ content (2.61 and $4.81 \mathrm{~g} / \mathrm{kg}$, respectively).

\section{CONCLUSIONS}

It may be concluded that the recommended dietary intake of $\mathrm{Na}$ for broiler chickens should be $1-1.2 \mathrm{~g} / \mathrm{kg}$ rather than $1.5-2.5 \mathrm{~g} / \mathrm{kg}$, and that relatively high DEB values (in excess of $200 \mathrm{mEq} / \mathrm{kg}$ ) do not meet the nutrient requirements of birds if the Na content of the ration is below $1 \mathrm{~g} / \mathrm{kg}$. The recommendations based on this study concerned $\mathrm{NaCl}$ as a sodium source; in this term using other sodium salts was the subject of our another work (Jankowski et al., 2011, in press).

\section{REFERENCES}

Aviagen Inc., 2007. Broiler Ross 308 Performance Objectives (available at http://www.aviagen. com $/$ ss $/$ ross-308/)

Bidar N., Rezaei M., Sayah Zadeh H., Kermanshahi H., 2007. Effect of feeding periods and levels of pre-starter diet on broiler performance and serum electrolytes. J. Anim. Vet. Adv. 6, 959-963

Borges S.A., Fischer da Silva A., Moura A., Maiorka A., Ostrensky A., 2004. Electrolyte balance in broiler growing diets. Int. J. Poultry Sci. 3, 623-628

Dahlqvist A., 1964. Method for assay of intestinal disaccharidases. Anal. Biochem. 7, 18-25

Djouzi Z., Andrieux C., 1997. Compared effect of the three oligosaccharides on metabolism of intestinal microflora in rats with human faecal flora. Brit. J. Nutr. 78, 313-324

Enting H., De Los Mozos J., Gutierrez Del Alamo A., Perez de Ayala P., 2009. Influence of minerals on litter moisture. In: Proceedings of $17^{\text {th }}$ European Symposium on Poultry Nutrition. Edinburgh (UK), pp. 47-52

Ferretti J.L., Capozza R.F., Mondel N., Zanchetta J.R., 1993. Interrelationships between densitometrical, geometric and mechanical properties of rat femurs. Inferences concerning mechanical regulation of bone modeling. J. Bone Miner. Res. 8, 1389-1396

Gal-Garber O., Mabjeesh S.J., Sklan D., Uni Z., 2003. Nutrient transport in the small intestine $\mathrm{Na}^{+}$, $\mathrm{K}^{+}$-ATPase expression and activity in the small intestine of the chicken as influenced by dietary sodium. Poultry Sci. 82, 1127-1133

GfE (Society of Nutrition Physiology), 1999. Empfehlungen zur Energie- und Nährstoffversorgung der Legehennen und Masthühner (Broiler). DLG Verlag. Frankfurt am Main 
Hurwitz S., Cohen L., Bar A., Bornstein S., 1973. Sodium chloride requirements of the chicken: relationship to acid-base balance. Poultry Sci. 52, 903-909

Jankowski J., Juśkiewicz J., Zduńczyk Z., Śmiecińska K., Kwieciński P., 2011. Effects of inclusion level and source of dietary sodium on performance and meat characteristics of broiler chickens. Arch. Anim. Nutr. 65, DOI: 10.1080/1745039X.2011.556331 (in press)

Juśkiewicz J., Jankowski J., Zduńczyk Z., Lecewicz A., Przybylska-Gornowicz B., Zięba M., 2009. Effect of diets with different contents of soybean $\alpha$-galactosides and crude fibre on modification of duodenal microstructure and selected parameters of nutrient utilization in young turkeys. Pol. J. Vet. Sci. 12, 455-463

Juśkiewicz J., Zduńczyk Z., 2004. Effects of cellulose, carboxymethylcellulose and inulin fed to rats as single supplements or in combinations on their caecal parameters. Comp. Biochem. Physiol. Pt. A 139, 513-519

Koreleski J., Świątkiewicz S., Arczewska A., 2010. The effect of dietary potassium and sodium on performance, carcass traits, and nitrogen balance and excreta moisture in broiler chicken. J. Anim. Feed Sci. 19, 244-256

Mongin P., 1981. Recent advantages in dietary anion-cation balance: Applications in poultry. Proc. Nutr. Soc. 40, 285-294

Murakami A. E., Saleh E. A., England J. A., Dickey E.N., Watkins S.E., Waldrup P.W., 1997. Effect of level and source of sodium on performance of male broilers to 56 days. J. Appl. Poultry Res. 6, 128-136

Murakami A. E., Saleh E. A., Watkins S.E., Waldrup P.W., 2000. Sodium sources and level in broiler diets with and without high levels of animal protein. J. Appl. Poultry Res. 9, 53-61

Musthaq T., Aslam Mirza M., Athar M., Hooge D.M., Ahmad T., Ahmad G., Mushtaq M.M.H., Noreen U., 2007. Dietary sodium and chloride for twenty-nine to forty-two-day-old broiler chickens at constant electrolyte balance under subtropical summer conditions. J. Appl. Poultry Res. 16, 161-170

Mushtaq T., Sarwar M., Nawaz H., Aslam Mirza M., Ahmad T., 2005. Effect on interactions of dietary sodium and chloride on broiler starter performance (hatching to twenty-eight days of age) under subtropical summer conditions. Poultry Sci. 84, 1716-1722

NRC, 1994. Nutrient Requirements of Poultry. $9^{\text {th }}$ revised Edition. National Academy Press. Washington, DC

Oviedo-Rondon E.O., Murakami A.E., Furlan A.C., Moreira I., Macari M., 2001. Sodium and chloride requirements of young broiler chickens fed corn-soybean diets (one to twenty-one days of age). Poultry Sci. 80, 592-598

Smulikowska S., Rutkowski A. (Editors), 2005. Nutrient Requirements of Poultry (in Polish). The Kielanowski Institute of Animal Physiology and Nutrition PAS, Jabłonna (Poland), pp. 41-47

Vieira S.L., Penz A.M., Pophal S., Godoy de Almeida J., 2003. Sodium requirements for the first seven days in broiler chicks. J. Appl. Poultry Res. 12, 362-370

Watkins S.E., Fritts C.A., Yan F., Wilson M.L., Waldroup P.W., 2005. The interaction of sodium chloride levels in poultry drinking water and the diet of broiler chickens. J. Appl. Poultry Res. $14,55-59$

Yu M.W., Robinson F.E., 1992. The application of short-term feed restriction to broiler chicken production. A review. J. Appl. Poultry Res. 1, 147-153 